\title{
Cellular hypersensitivity to gluten derived peptides in coeliac disease
}

\author{
R GUAN, P M RAWCLIFFE, J D PRIDDLE, AND D P JEWELL
}

From the Gastroenterology Unit, Radcliffe Infirmary, Oxford

SUMMARY Wheat gluten derived antigens have been tested for their ability to inhibit the migration of leucocytes from healthy subjects and patients with coeliac disease. Three preparations of a water soluble fraction (Frazer's fraction III, FIII) of partial peptic tryptic digests of wheat gluten had different effects in a direct (one stage) assay. Subfractions B and B2 caused migration inhibition of leucocytes from patients with treated coeliac disease but not of leucocytes from healthy volunteers or patients with Crohn's disease or ulcerative colitis. This migration inhibition seems to be specific for gluten fractions because maize zein fraction $\mathrm{B}, \boldsymbol{\beta}$-lactoglobulin and ovalbumin did not cause it. The sensitivity of coeliac leucocytes to fraction $B$ is not related to factors present in coeliac serum as the migration of leucocytes from healthy individuals preincubated with coeliac sera was not inhibited. Puromycin diminished inhibition by fraction B, which was active at $1.2 \mu \mathrm{g} / \mathrm{ml}$ in an indirect (two stage) migration inhibition assay; this is consistent with a process involving elaboration of lymphokine(s). More highly purified fractions of B2, P1-P4 were prepared by reverse phase high performance liquid chromatography (HPLC) and showed differing potency in direct and indirect assays, with P4 being the most active fraction. Inhibition of migration by gluten derived peptides appears to result from the release of lymphokine by leucocytes specifically from coeliac patients.

Since Dicke' first established the toxicity of wheat gluten in patients with coeliac disease there have been numerous attempts to identify its toxic component. Frazer $e t a^{2}$ showed that a water soluble fraction (fraction III, FIII) of a partial peptic tryptic digest of gluten retained its damaging properties. Dissanayake et $^{3}{ }^{3}$ separated FIII into three fractions ( $\mathrm{A}, \mathrm{B}$, and $\mathrm{C})$ by ultrafiltration. By feeding studies, in volunteer patients with treated coeliac disease, they showed that fraction A (lowest molecular weight) was not harmful, but that fractions $B$ and $C$ produced histological damage. Anand $e t \mathrm{al}^{4}$ separated fraction $B$ into further subfractions by gel filtration on Sephadex G50. Of the three subfractions separated, those with the higher molecular weights (B2 and B3) were found to be toxic by feeding. Working with intact gliadins, de Rooij et al ${ }^{5}$ have shown the toxicity

Address for correspondence: Dr D P Jewell, Gastroenterology Unit, Radeliffe Infirmary, Oxford, OX2 6HE.

Received for publication 23 July 1986. of alpha gliadins by instillation and Ciclitira et $a l^{b}$ have demonstrated the toxicity of alpha, beta, gamma, and omega gliadins.

The ultimate test of toxicity remains the demonstration of histological damage in vivo, but as fractions are progressively purified it becomes increasingly difficult to prepare sufficient quantities for feeding experiments in coeliac patients and in vitro experiments become necessary. While the mechanism by which gluten produces mucosal damage in patients with coeliac disease is unknown, there is now a considerable body of evidence implicating immunological mechanisms.

Several groups have studied cellular immune reactions to gluten fractions in vitro, principally by the leucocyte migration inhibition assay which is usually held to be a measure of cell mediated immunity. ${ }^{710}$ While much migration inhibition testing has been done by the capillary tube method, it is more difficult to perform and less sensitive than the 
agarose gel technique described by Clausen." The following experiments were carried out by the latter method to determine the cellular responses to the gluten fractions FIII, B and B2, and to confirm the specificity of these responses for coeliac disease.

More recently, fraction B2 has been further separated using reverse-phase HPLC. The peaks fell into four main groups, designated P1 to P4, each containing several peptides. ${ }^{12}$ Results using these peptide fractions in both the direct and the indirect leucocyte migration inhibition assay are described.

\section{Methods}

\section{PATIENTS}

Twenty two patients with coeliac disease were studied. All had villous atrophy consistent with coeliac disease at the time of presentation, and all had a good clinical and histological response to a gluten free diet and remained well on the diet at the time of testing.

Two groups of similar age and sex distribution were chosen as controls; 13 hospital staff and 10 patients with quiescent inflammatory bowel disease (one with chronic colitis of undetermined type; four with ulcerative colitis; and five with Crohn's disease of whom two had colitis, one had terminal ileal disease, and two had both ileal and colonic disease). No patient was being treated with corticosteroids or immunosuppressives.

\section{GLUTEN FRACTIONS}

Fraction III from a peptic tryptic digest of gluten was prepared by the method of Frazer $e t$ al ${ }^{2}$ in Leeds (from commercial gluten derived from a mixture of wheat varieties, British Drug Houses) and in Oxford (from Flanders and Scout 66 wheats).

Trypsin inactivated FIII (Flanders) was prepared by heating FIII to $90^{\circ} \mathrm{C}$ for 30 minutes. The absence of tryptic activity was confirmed by the method of Rick. ${ }^{13}$

Fraction B and fraction B2, were prepared from Scout 66 wheat according to the methods of Dissanayake et $a l^{3}$ and Anand ${ }^{14}$ respectively. This preparation of fraction $B$ has been found to produce mucosal damage in feeding experiments and the B2 used in the present study was made from it. The peptide groups P1 to P4 were derived by reverse phase HPLC from a new sample of B2, as described by Rawcliffe et al. ${ }^{\prime 2}$

Two preparations of gliadins were made from Flanders wheat. The first was prepared by Sephacryl S200 gel filtration to remove omega gliadins and glutenins and to yield alpha/beta/gamma gliadins. This preparation was subjected to CM52 ion exchange chromatography in urea containing buffers to give a second preparation designated 'late eluting' gliadins (predominantly alpha gliadins by starch gel electrophoresis, details of this unpublished work are available on request). Purified protein derivative of human tuberculin (Central Veterinary Laboratory, Surrey, England) was used as a positive control antigen.

Maize zein fraction B (prepared in a similar manner to wheat gluten fraction B), bovine $\beta$-lactoglobulin (Sigma), and chicken ovalbumin (Pharmacia) were also used as test antigens.

\section{DIRECT LEUCOCYTE MIGRATION INHIBITION} ASS A Y

This was carried out by the method of Clausen." 30 $\mathrm{ml}$ heparinised blood was mixed with $8 \mathrm{ml} 6 \% \mathrm{w} / \mathrm{v}$ Dextran 150 (MW 150000) in $0.9 \% \mathrm{NaCl}$ (Fisons, Loughborough, England) and left to sediment at $37^{\circ} \mathrm{C}$ for 45 minutes. The buffy coat was removed, washed three times with Hanks' Balanced Salt Solution (HBSS; Gibco, Paisley, Scotland) and resuspended in RPMI 1640 culture medium with 25 $\mathrm{mM}$ Hepes and L-glutamine (Gibco) containing $10 \%$ heat inactivated fetal calf serum (Gibco). The leucocyte yield was usually about $100 \times 10^{6}$ (range $\left.50-130 \times 10^{6}\right)$ and consisted of approximately $80 \%$ granulocytes and $20 \%$ lymphocytes. The erythrocyte:leucocyte ratio was 1:1.

Agarose (Indubiose A45; Uniscience Ltd, London SW18 2LS, England) was added to sterile water, boiled to dissolve it and cooled to $47^{\circ} \mathrm{C}$. At that temperature horse serum (Wellcome, Beckenham, England) and 10× concentrated TC199 culture medium (Wellcome) were added to a final concentration of $10 \%$ each. Final concentration of agarose was $1 \% .7 \cdot 5 \% \mathrm{NaHCO}_{3}$ solution (Flow Laboratories, Rickmansworth, England) was added so that the $\mathrm{pH}$ of the medium after incubation in $5 \% \mathrm{CO}_{2}$ in air was between $7 \cdot 2$ and 7.4. Penicillin $(66 \mathrm{IU} / \mathrm{ml}$; Glaxo, Greenford, England) and streptomycin $(66 \mu \mathrm{g} / \mathrm{ml}$; Evans Medical, Greenford, England) were also included. $10 \mathrm{ml}$ agarose - serum - TC199- $\mathrm{NaHCO}_{3}$ solution were then poured into disposable $9 \mathrm{~cm}$ diameter plastic Petri dishes and wells of $2 \mathrm{~mm}$ diameter were punched out in the gel after it had solidified.

The leucocytes were preincubated with antigens as follows: aliquots of the cell suspension were placed in $1.5 \mathrm{ml}$ plastic centrifuge tubes, antigen was added and the mixture incubated for 30 minutes at $37^{\circ} \mathrm{C}$. Antigens were tested at final concentrations from 10 $\mu \mathrm{g} / \mathrm{ml}$ to $1 \mathrm{mg} / \mathrm{ml}$. Phosphate buffered saline was added to the control suspension instead of antigen. Cell viability after incubation was assessed by Trypan blue dye exclusion and $5 \mu \mathrm{l}$ of each suspension (final cell concentration $300 \times 10^{\circ} / \mathrm{ml}$ ) were placed in the agarose wells. Most samples were assayed in quad- 
ruplicate (triplicate in a few cases) and, if more than one plate was used in testing an individual, control wells were included in each plate. The Petri dishes were incubated for 18 hours at $37^{\circ} \mathrm{C}$ in a humidified atmosphere of $5 \% \mathrm{CO}_{2}$ in air. The cells were fixed with $95 \%$ alcohol for six hours or more. The agarose was then gently lifted from the dishes and the areas of migration projected onto a Kontron MOP-AMO3 electronic area measurement tablet. This was programmed to measure the area of the image outlined by a measuring pen.

A migration index was calculated:

Mean migration area of four wells with Migration index $(\mathrm{MI})=\frac{\text { antigen }}{\text { Mean migration area of four control wells }}$

Results were analysed statistically by the unpaired Student's $t$ test.

Puromycin (Sigma) at a final concentration of 15 $\mu \mathrm{g} / \mathrm{ml}$, together with fraction $\mathrm{B}$ at $100 \mu \mathrm{g} / \mathrm{ml}$, was incubated with leucocytes from four coeliac patients.

\section{INDIRECT LEUCOCYTE MIGRATION INHIBITION}

ASSAY

Heparinised peripheral venous blood, diluted with an equal volume of HBSS, was layered onto a FicollPaque (Pharmacia) gradient and centrifuged at 1200 rpm for 35 minutes. The mononuclear cells at the interface were removed, washed twice with HBSS and resuspended at $1.5 \times 10^{h}$ cells/ $\mathrm{ml}$ in RPMI 1640 containing $10 \%$ fetal calf serum. $1 \mathrm{ml}$ aliquots were dispensed into upright plastic culture tubes with or without $1.2 \mu \mathrm{g} / \mathrm{ml}$ of fraction B.

Cultures were incubated for 72 hours, the cell suspensions centrifuged and the supernatant diluted 1:1 with fresh RPMI 1640. The unstimulated culture supernatants were reconstituted with appropriate concentrations of antigens. Leucocyte suspensions, prepared by dextran sedimentation from the blood of healthy donors, were used as indicators for measurement of migration inhibitory activity in these supernatants. For the indirect test, migration index (MI) was calculated as follows:

Mean migration area of four wells with supernatant from cells incubated with antigen

Mean migration area of four wells with supernatant from control cells reconstituted with antigen

\section{SERUM PREINCUBATION}

Ten microlitre aliquots of buffy coat cells $(300 \times$ $10 \% / \mathrm{ml}$ ) from a healthy individual were incubated at $37^{\circ} \mathrm{C}$ for one hour with $20 \mu \mathrm{l}$ serum from eight coeliac patients and from five normal individuals. The cells were then washed twice and used in the direct migration inhibition assay with fraction $\mathrm{B}$ as antigen $(100 \mu \mathrm{g} / \mathrm{ml})$.

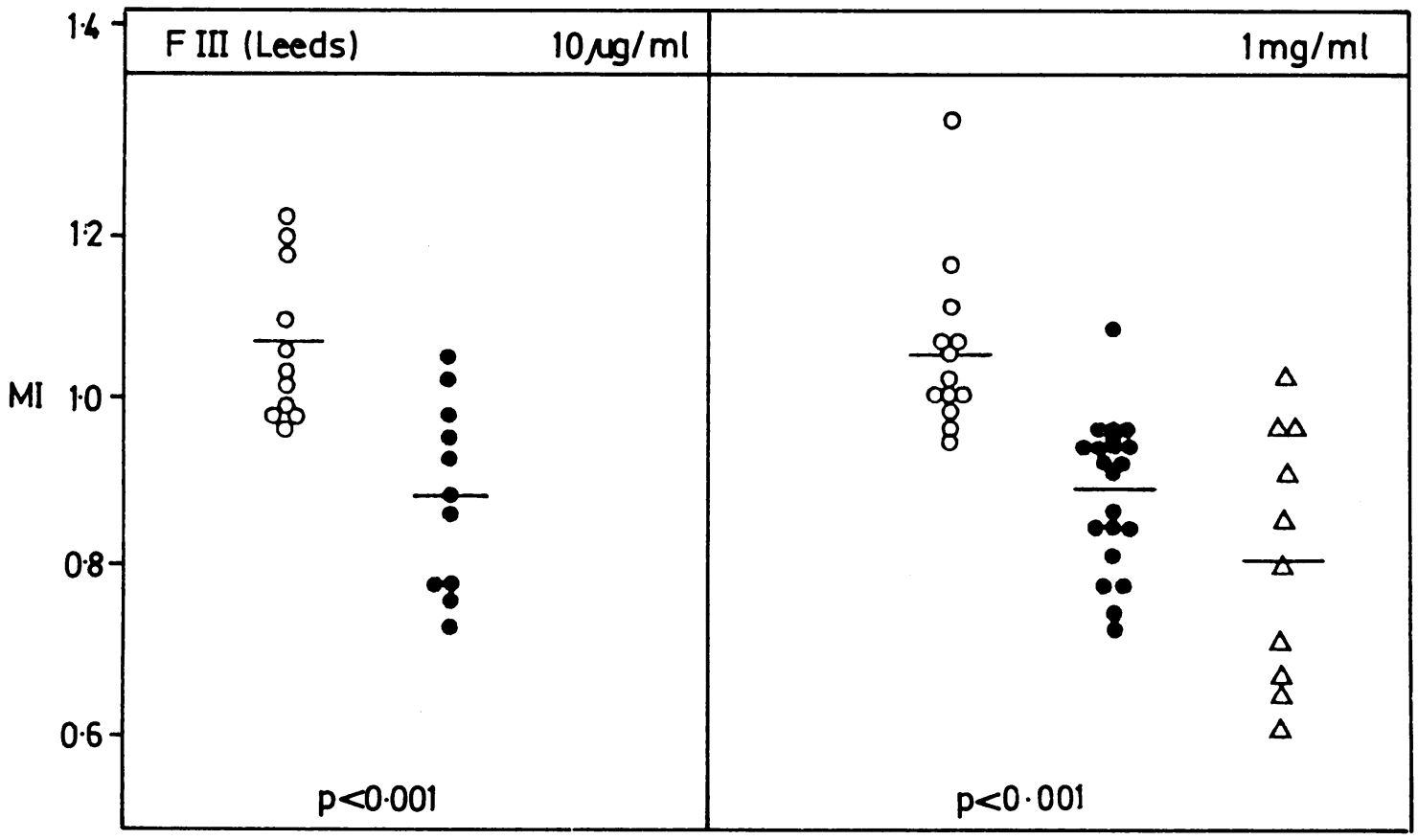

Fig. 1 Effect of FIII (Leeds) on leucocyte migration in normal individuals, patients with coeliac disease and patients with ulcerative colitis or Crohn's disease (disease controls), at doses of $10 \mu \mathrm{g} / \mathrm{ml}$ and $1 \mathrm{mg} / \mathrm{ml} . \bigcirc=$ healthy control. $O=$ coeliac disease. $\triangle=$ disease control. 


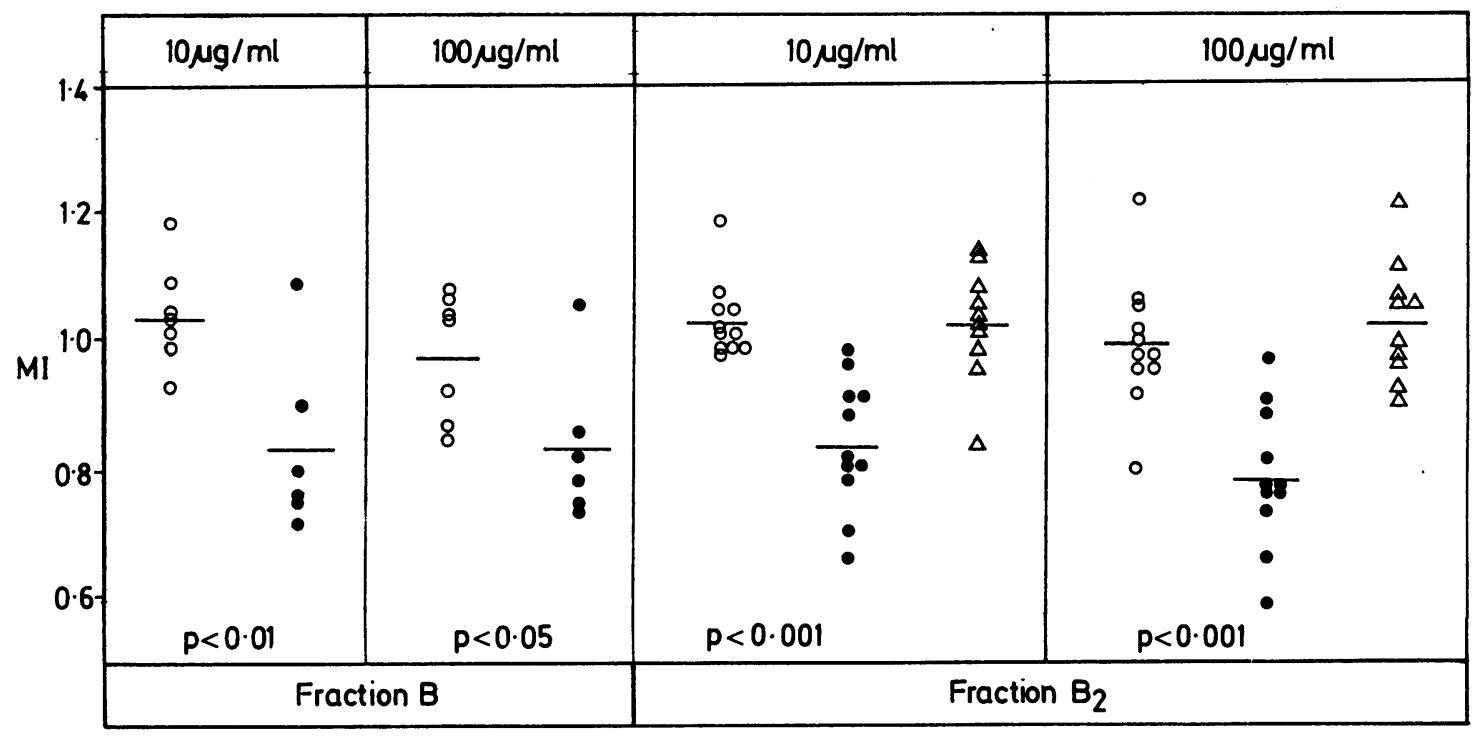

- Healthy control - Coeliac disease $\triangle$ Disease control

Fig. 2 Effect of fractions $B$ and $B 2$ on leucocyte migration in healthy individuals, patients with coeliac disease and patients with inflammatory bowel disease (disease controls) at $10 \mu \mathrm{g} / \mathrm{ml}$ and $100 \mu \mathrm{g} / \mathrm{ml}$ ).

\section{Results}

The areas of migration were well defined. There was less than $10 \%$ variation between the areas of migration of quadruplicate wells. Preliminary experiments showed that the presence of erythrocytes or slight variation of $\mathrm{pH}$ from $7 \cdot 2$ to $7 \cdot 4$ did not interfere with the test. There was no difference in Trypan blue dye exclusion by cells incubated with or without antigens (except in the cases with high doses noted below), indicating that cell death was not the cause of any inhibition of migration.

Using purified protein derivative as antigen, leucocytes from patients with coeliac disease behaved like those from healthy individuals, migration being depressed by $100 \mu \mathrm{g} / \mathrm{ml}$ purified protein derivative (healthy controls $(n=8)$, mean migration index $=$ 0.76 ; coeliac patients $(n=19)$, mean migration index $=0.78$ ).

Frazer's fraction III prepared in Oxford from Flanders wheat as well as from Scout 66 wheat had no effect on the migration of leucocytes from either healthy individuals or patients with coeliac disease at concentrations as high as $1 \mathrm{mg} / \mathrm{ml}$ (Flanders fraction III: healthy controls $(n=7)$, mean migration index $=$ $1 \cdot 12$; coeliacs $(n=14)$, mean migration index $=1 \cdot 08$; no significant difference, $p>0 \cdot 1$; Scout 66 fraction III: healthy controls $(n=7)$, mean migration index $=$ $1 \cdot 10$; coeliacs $(n=7)$, mean migration index $=1 \cdot 08$; no significant difference, $p>0.5$ ) (Fig. 1). Flanders fraction III, however, showed a lower migration index after inactivation of trypsin with both normal $(p<0.02)$ and coeliac $(p<0.05)$ leucocytes.

Fraction III from Leeds inhibited leucocyte migration in patients with coeliac disease at $1 \mathrm{mg} / \mathrm{ml}$ (compared with healthy controls, $\mathrm{p}<0 \cdot 001)$. Significant inhibition was seen even at $10 \mu \mathrm{g} / \mathrm{ml}$ (compared with healthy controls, $p<0.001)$. This antigen also inhibited the migration of leucocytes from patients in the disease control group at $1 \mathrm{mg} / \mathrm{ml}$ (Fig. 1).

Alpha/beta/gamma gliadins $(100 \mu \mathrm{g} / \mathrm{ml}$ and $1 \mathrm{mg} / \mathrm{ml}$ ) failed to inhibit the migration of leucocytes from either coeliac patients or normal individuals $(100 \mu \mathrm{g} / \mathrm{ml}$ : healthy controls $(\mathrm{n}=7)$, mean migration index $=0.96$; coeliacs $(n=6)$, mean migration index $=$ $0 \cdot 98.1 \mathrm{mg} / \mathrm{ml}$ : healthy controls $(\mathrm{n}=7)$, mean migration index $=0.99$; coeliacs $(n=6)$, mean migration index $=0.92$ ). 'Late-eluting' gliadins, however, tended to inhibit migration of leucocytes from coeliac patients at $100 \mu \mathrm{g} / \mathrm{ml}$, although this did not reach statistical significance at the $5 \%$ level $(10 \mu \mathrm{g} / \mathrm{ml}$ : healthy controls $(n=11)$, mean migration index= $1 \cdot 07$; coeliacs $(n=9)$, mean migration index $=1 \cdot 01$; $\mathrm{p}>0 \cdot 1.100 \mu \mathrm{g} / \mathrm{ml}$ : healthy controls $(\mathrm{n}=11)$, mean migration index $=1.00$; coeliacs $(n=11)$, mean migration index $=0 \cdot 89 ; 0 \cdot 1>p>0 \cdot 05)$.

Fractions B and B2 of Scout 66 wheat had no effect on the migration of leucocytes from healthy subjects (Fig. 2). For fraction B the largest difference between patients and healthy controls was at $10 \mu \mathrm{g} / \mathrm{ml}$ $(p<0 \cdot 01)$. For subfraction B2 the difference was greatest at $100 \mu \mathrm{g} / \mathrm{ml}(\mathrm{p}<0.001)$ (Fig. 3). The migra- 


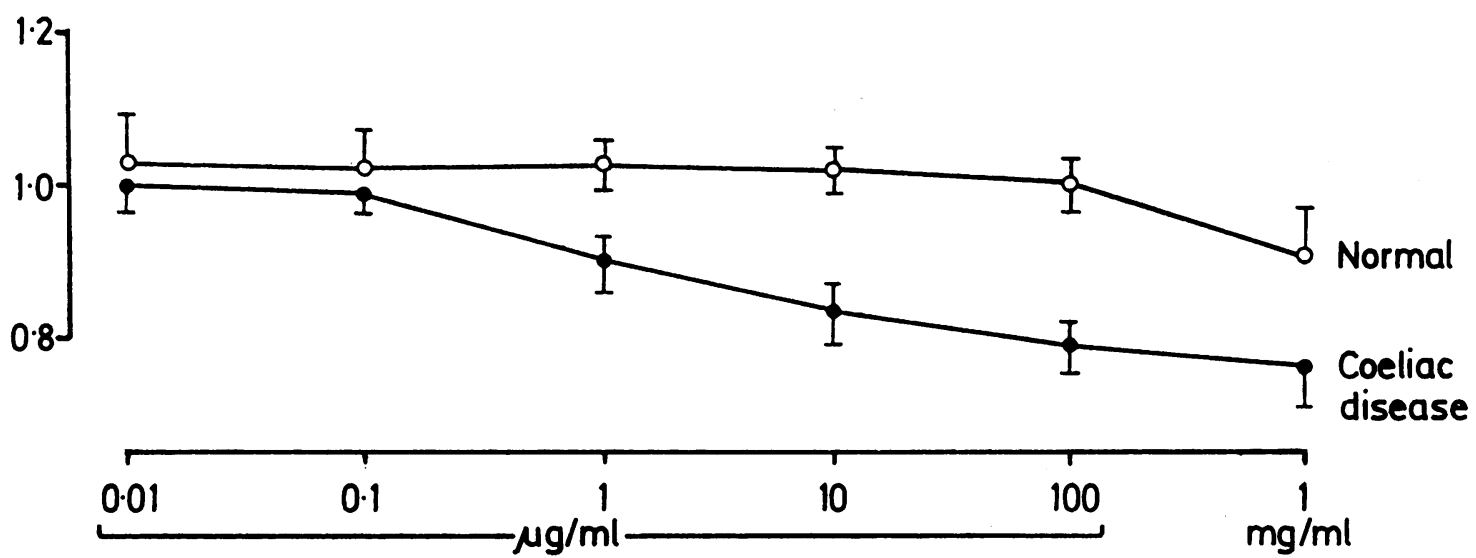

Fig. 3 Migration indices of leucocytes from healthy individuals and patients with coeliac disease exposed to different concentrations of gluten fraction B2. Error bars show SEM.

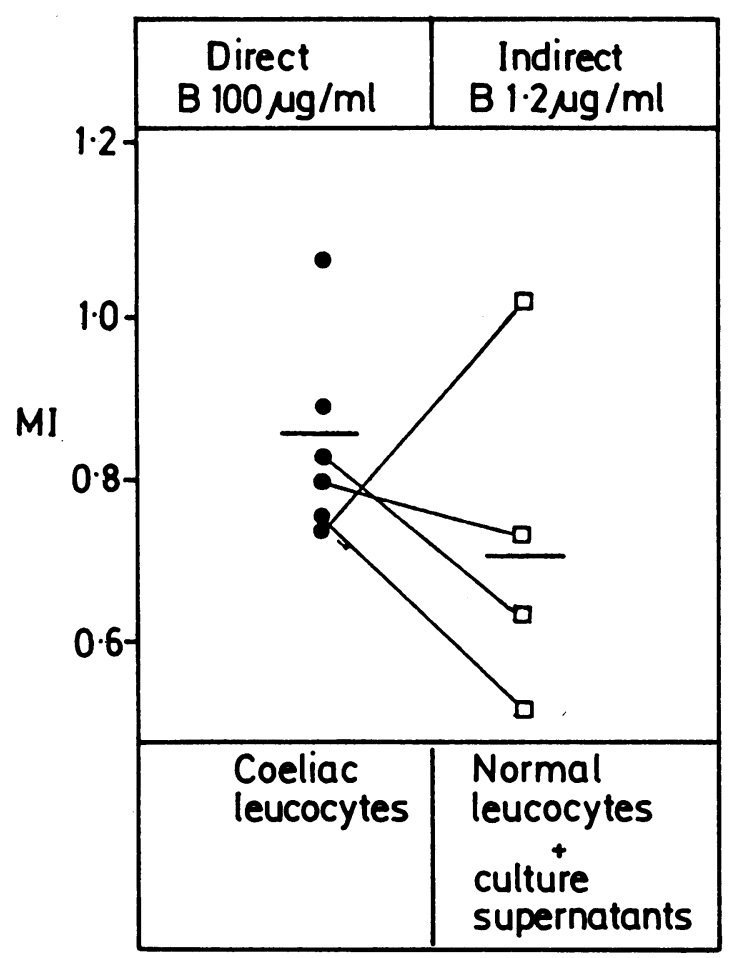

Fig. 4 Effect of fraction $B$ in the indirect leucocyte migration inhibition assay. Filled circles $(\mathbf{)}$ ) show the migration indices in the direct assay for leucocytes from six coeliac patients incubated with fraction $B$ at $100 \mu \mathrm{g} / \mathrm{ml}$. Peripheral blood mononuclear cells from the four patients with the lowest values in the direct assay were incubated with fraction $B$ at $1 \cdot 2 \mu \mathrm{g} / \mathrm{ml}$ and the effect of the culture supernatants on the migration of normal leucocytes tested in the indirect assay is shown as open squares $(\square)$. Lines connect the results in the two different assays for the same patient. tion index for normal controls fell below 1.0 at the highest dose of $1 \mathrm{mg} / \mathrm{ml}$ when a reduction in cell viability was seen after the preincubation period.

The migration of leucocytes from patients with coeliac disease was not significantly inhibited by zein fraction $B(100 \mu \mathrm{g} / \mathrm{ml}$ : healthy controls $(\mathrm{n}=8)$, mean migration index $=1.09$; coeliacs $(n=12)$, mean migration index $=1.05)$, nor by $\beta$-lactoglobulin $(100 \mu \mathrm{g} / \mathrm{ml}$ : healthy controls $(n=8)$, mean migration index $=1 \cdot 01$; coeliacs $(n=12)$, mean migration index $=1 \cdot 08)$, nor by ovalbumin $(100 \mu \mathrm{g} / \mathrm{ml}$ : healthy controls $(n=6)$, mean migration index $=0.99$; coeliacs $(n=10)$, mean migration index $=1 \cdot 06$ ).

Puromycin at $15 \mu \mathrm{g} / \mathrm{ml}$ diminished migration inhibition by fraction B at $100 \mu \mathrm{g} / \mathrm{ml}$ in three of four coeliac patients.

The results of an indirect assay with fraction $B$ are shown in Figure 4. The migration of normal leucocytes is inhibited by culture supernatants of peripheral blood mononuclear cells from patients with coeliac disease incubated with fraction $\mathrm{B}$ at $1 \cdot 2$ $\mu \mathrm{g} / \mathrm{ml}$. In contrast, the results shown for the direct assay are with 80 times as much antigen.

Preincubation of normal leucocytes with sera from eight patients with coeliac disease did not sensitise these cells to the antigen, fraction $B$ at $100 \mu \mathrm{g} / \mathrm{ml}$ (mean migration index of normal leucocytes exposed to coeliac sera $=0.94$; mean migration index of normal leucocytes exposed to normal sera $=1.04$; not significantly different, $p>0 \cdot 1$ ).

A comparison of the results of the direct migration inhibition assay using gluten fraction $\mathrm{B} 2$ of Anand $e t$ $a l^{1+}$ and the new fraction B2 shows that these two fractions both inhibit the migration of leucocytes from coeliac patients to the same extent. Leucocytes from healthy subjects show very little inhibition with either fraction. In the disease controls there was no 


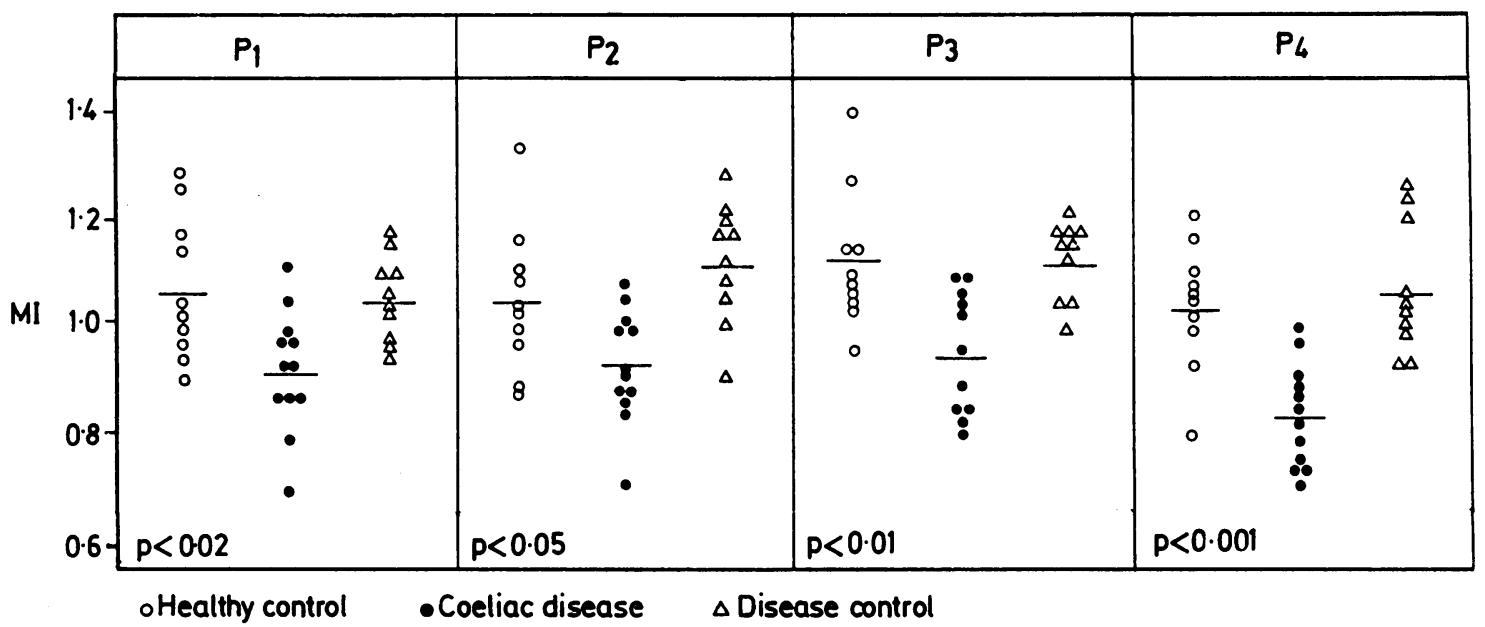

Fig. 5 Migration indices of leucocytes from normal individuals, patients with coeliac disease, and patients with inflammatory bowel disease (disease controls) after exposure to peptide groups from RP-HPLC, at $100 \mu \mathrm{g} / \mathrm{ml}$. p values compare coeliac disease patients with healthy controls.

difference between the two fractions: for B2 at $10 \mu \mathrm{g} / \mathrm{ml}$, mean migration index $=1.03(\mathrm{n}=10, \mathrm{SD}=$ 0.09 ), while for new $B 2$ at the same concentration, mean migration index $=1.03(n=10, S D=0 \cdot 10)$.

For $\mathrm{B} 2$ at $100 \mu \mathrm{g} / \mathrm{ml}$, mean migration index $=1.04$ $(n=10, S D=0 \cdot 09)$, while for new $B 2$ at the same concentration, mean migration index $=1.06(n=10$, $\mathrm{SD}=0 \cdot 16)$.

Figures 5 and 6 show the migration indices of leucocytes from normal individuals, patients with coeliac disease and disease controls exposed to 10 $\mu \mathrm{g} / \mathrm{ml}$ and $100 \mu \mathrm{g} / \mathrm{ml}$ of each of the peptide groups $\mathrm{P} 1$ to $\mathrm{P} 4$. There was significant migration inhibition of leucocytes from coeliac patients exposed to all four peptide groups. The migration indices in coeliac patients were lowest with fraction P4 (compared with healthy controls, $100 \mu \mathrm{g} / \mathrm{ml}: \mathrm{p}<0.001,10 \mu \mathrm{g} / \mathrm{ml}$ : $\mathrm{p}<0 \cdot 01)$.

When leucocytes from healthy individuals were exposed in the indirect assay to the culture supernatants from mononuclear cells of five coeliac patients that had been incubated with antigens, their migration was inhibited (Fig. 7). The antigens used to stimulate the coeliac cells were P1 and P3 at 1.2 $\mu \mathrm{g} / \mathrm{ml}$.

\section{Discussion}

The inhibition of migration of leucocytes by purified protein derivative in both healthy individuals and

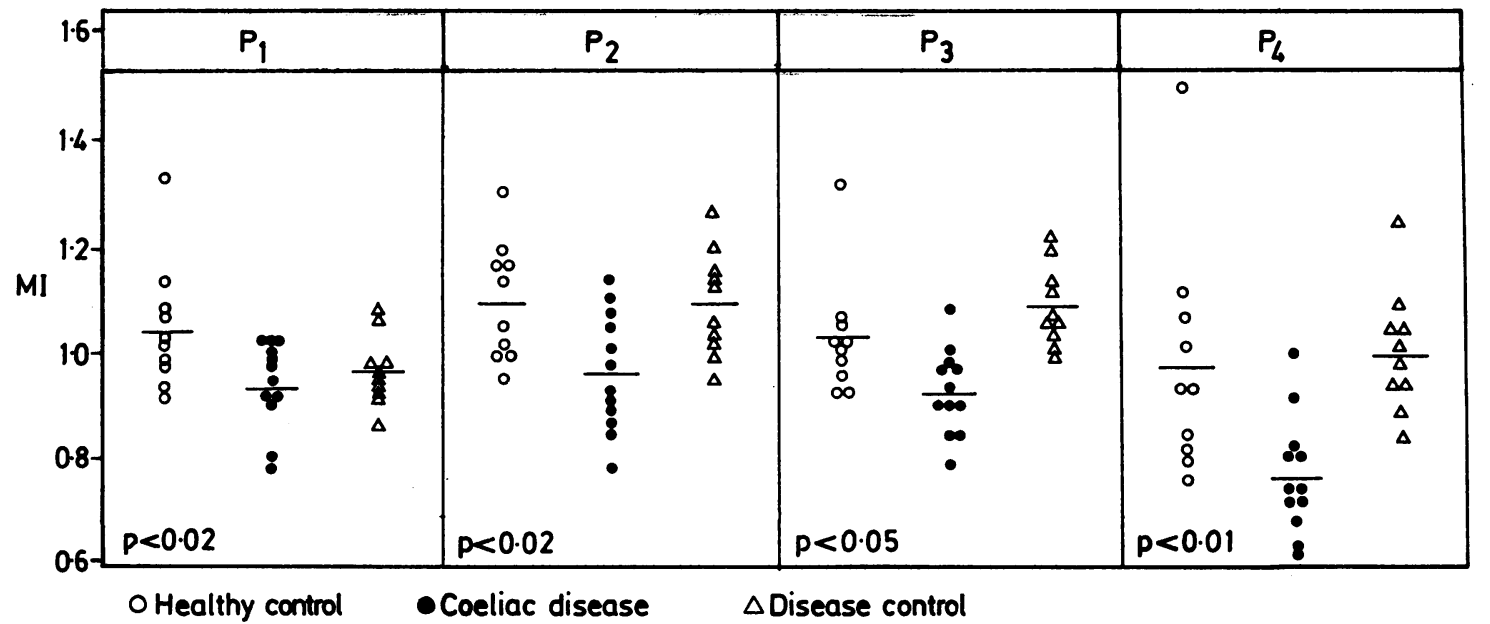

Fig. 6 Migration indices as Figure 5, but at $10 \mu \mathrm{g} / \mathrm{ml}$. 

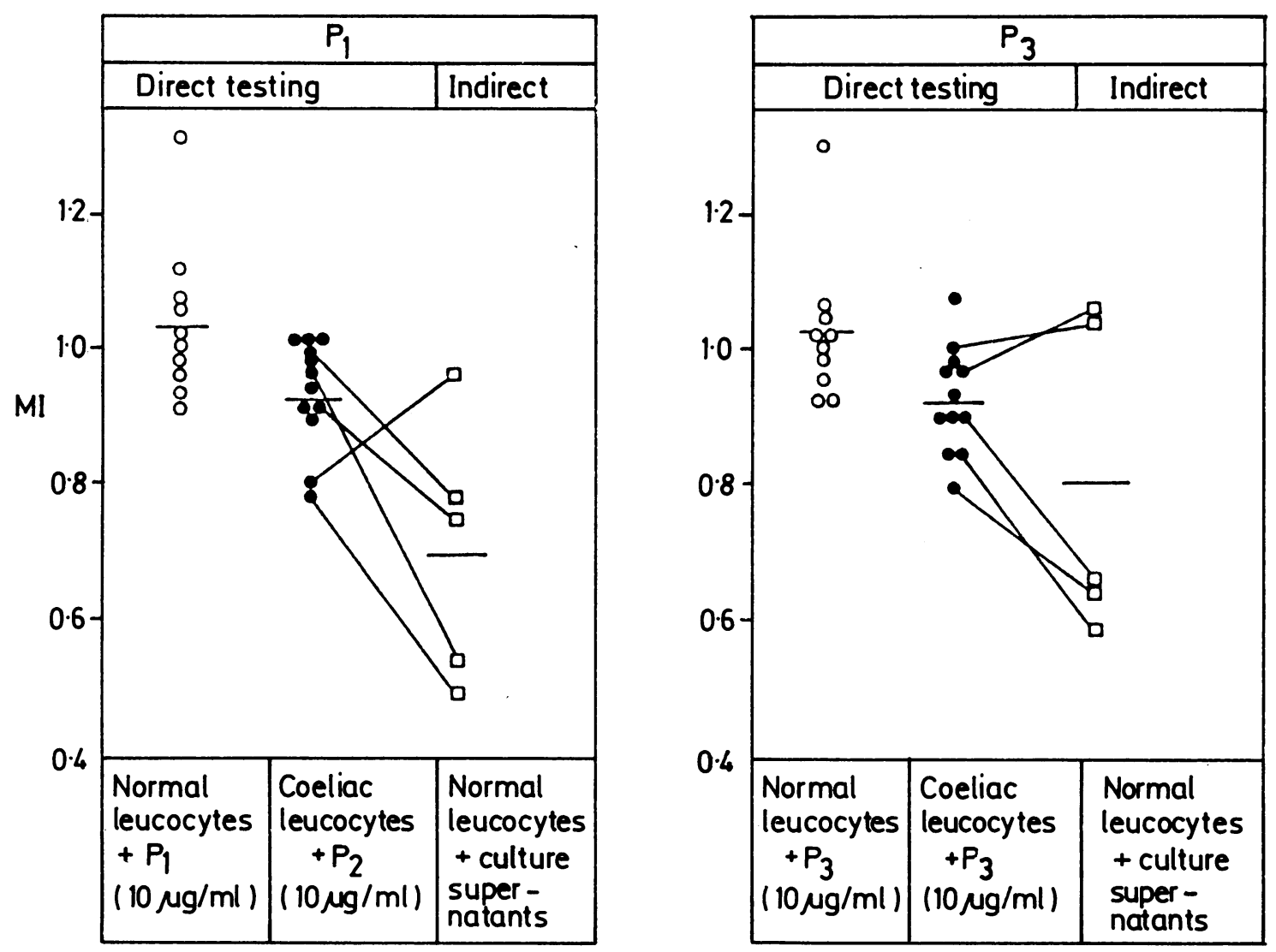

Fig. 7 Indirect leucocyte migration inhibition assays, for peptide groups PI and P3 (the data for the direct testing are shown for comparison). Migration indices of normal leucocytes exposed to culture supernatants of mononuclear cells from five coeliac patients incubated with $1.2 \mu \mathrm{g} / \mathrm{ml}$ of PI and P3. Tie lines connect results for the same patient.

patients with coeliac disease suggests that the lymphocytes from the patients retain their ability to produce migration inhibition factor(s) when stimulated with recall antigens.

FIII has been shown to be toxic to the coeliac intestinal epithelium by feeding experiments (reference 2 and, for Scout 66, P M Rawcliffe, unpublished work). FIII has also been reported to cause inhibition of migration of leucocytes in patients with coeliac disease. ${ }^{7}$ O'Farrelly et al,${ }^{15}$ however, failed to confirm this response. Four preparations of FIII were tested in the present study and a positive response found to the preparation from Leeds but not to those prepared in Oxford. Gel filtration on Sephadex G-50 in Oxford has shown the presence of large molecular weight material in the preparation from Leeds which was not found in the local FIII (P M Rawcliffe and J D Priddle, unpublished observations). This may represent large fragments of gluten and could explain a recent report from Leeds that migration inhibition of coeliac leucocytes by
FIII (Leeds) might not be caused by lymphokine activity. ${ }^{16}$ It is conceivable that the large molecular weight material in the Leeds preparation could bind to cytophilic antibodies present on the leucocytes of patients with coeliac disease. This mechanism could explain the low migration indices with this antigen in patients in our disease control group. Although direct cytotoxicity cannot be ruled out completely by Trypan blue exclusion, it is probably not the reason for the observed low migration index in these patients as healthy individuals showed no migration inhibition with the same dose of the antigen (Leeds FIII, $1 \mathrm{mg} / \mathrm{ml}$ ).

Gliadins have been held to induce cell mediated

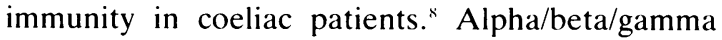
gliadins prepared in Oxford failed to inhibit the migration of leucocytes from patients with coeliac disease. O'Farrelly and coworkers ${ }^{15}$ obtained a similar result with mixed gliadins, using the capillary tube method. They found, however, migration inhibition with coeliac leucocytes exposed to purified 
alpha-, beta-, and gamma-gliadins separately. Migration inhibition with $100 \mu \mathrm{g} / \mathrm{ml}$ of 'late-eluting' gliadins prepared in Oxford did not reach statistical significance and experiments with larger doses were not done.

We believe it is important that inhibition of the migration of leucocytes from coeliac patients has been demonstrated for fraction B which causes histological damage to the coeliac small intestinal mucosa in vivo. The sensitivity of coeliac leucocytes to fraction $B$ is unrelated to factors present in coeliac serum. Gluten fraction B is effective in both direct and indirect migration inhibition tests at very low doses, and its action is abolished by puromycin. This suggests that the cellular hypersensitivity of patients with treated coeliac disease to gluten peptides is mediated by soluble factors (lymphokines). $\beta$ lactoglobulin, ovalbumin and maize zein fraction B did not cause migration inhibition of leucocytes from patients with coeliac disease, so the observed responses to gluten may be of considerable significance in the pathogenesis of the disease, rather than merely an immune response consequent on loss of mucosal integrity.

Gluten is a complex material which contains many proteins with closely similar physical characteristics and overall chemical composition. The available evidence suggests that they show a considerable degree of structural homology, both between and within individual gliadin molecules. The result of an incomplete peptic tryptic digest of gluten under the conditions of Frazer $e t$ al is yet more complex.

Fractions B and B2 inhibit migration of coeliac leucocytes while the preparation of Scout 66 FIII from which they derive does not. Ashkenazi and coworkers $^{17}$ found that migration inhibition was more marked when leucocytes from coeliac patients were incubated singly with either their B2 or their B3 subfraction than when they were incubated with a mixture of the two or with their FIII. They speculated that fractionation of FIII into smaller peptides uncovers immunogenic sites which are again masked by remixing these fractions.

We have shown no effect of fractions B and B2 in healthy controls. Other workers ${ }^{18}$ have noted cell mediated immunity to our fraction B2 in non-coeliac patients with active small bowel diseases.

Fraction B2 has now been separated into four peak groups, ${ }^{12}$ each still containing many peptides, by reverse phase HPLC. All four peptide groups caused migration inhibition of leucocytes from patients with coeliac disease in the direct assay, at low concentrations. P4 was the most active. This effect was only seen with coeliac patients. The ability of culture supernatants to inhibit the migration of leucocytes from normal individuals suggests that lymphokine is produced by the stimulation of mononuclear cells from patients with coeliac disease by gluten derived peptides.

The indirect test was not performed with peptide groups $\mathrm{P} 2$ and $\mathrm{P} 4$ because of a lack of materials. Any 'active sequence' (or sequences) could be present in many of the peptides resulting from the partial digestion procedure used here. It need not therefore be surprising, at this level of separation, that all four peptide groups, each with a number of peptides, exhibit some degree of activity. They are the subject of further studies.

We are grateful to Dr Peter Howdle, St James's Hospital, Leeds, for supplying us with their preparation of Frazer's fraction III. RG was supported by the University of Singapore and the Coeliac Trust; PMR by the Medical Research Council and Welfare Foods (Stockport) Ltd, and JDP by the Wellcome Trust and Welfare Foods Ltd.

\section{References}

1 Dicke WK. Coeliake. Utrecht: MD thesis, 1950.

2 Frazer AC, Fletcher RF, Ross CAC, Shaw B, Sammons HG, Schneider R. Gluten-induced enteropathy. The effect of partially digested gluten. Lancet 1959; ii: 252-5.

3 Dissanayake AS, Jerrome DW, Offord RE, Truelove SC, Whitehead R. Identifying toxic fractions of wheat gluten and their effect on the jejunal mucosa in coeliac disease. Gut 1974; 15: 931-45.

4 Anand BS, Offord RE, Piris J, Truelove SC. Isolating the component of gluten which causes the mucosal damage in coeliac disease. [Abstract] Gut 1977; 18: A408.

5 de Rooij FWM, van Duyn W, Lems-van Kan PH, Hekkens WThJM. The heterogeneity of alpha-gliadin. In: McNicholl B, McCarthy CF, Fottrell PF, eds. Perspectives in coeliac disease. Lancaster: MTP Press, 1978: 17-24.

6 Ciclitira PJ, Evans DJ, Lennox ES, Fagg NLK, Dowling $\mathrm{RH}$. The toxic effects of gliadin fractions on the small bowel mucosa of patients with coeliac disease. Clin Sci 1982; 62: 48P.

7 Bullen AW, Losowsky MS. Cell mediated immunity to gluten fraction III in adult coeliac disease. Gut 1976; 17: 813.

8 Douwes FR, Lippmann-Nielsen I, Hanke R. Gliadininduzierte Migrationshemmung peripherer Leukozyten in der Agaroseplattentechnik bei Patienten mit Coeliakie. (Gliadin-induced migration inhibition of peripheral leucocytes by the agarose technique in patients with coeliac disease). Dtsch Med Wochenschr 1977; 102: 721-4.

9 Haeney MR, Asquith P. Inhibition of leucocyte migration by $\alpha$-gliadin in patients with gastrointestinal disease: its specificity with respect to $\alpha$-gliadin and coeliac disease. In: McNicholl B, McCarthy CF, Fottrell PF, 
eds. Perspectives in coeliac disease. Lancaster: MTP Press, 1978: 229-42.

10 O'Farrelly C, Feighery C, Greally JF, Weir, DG. Cellular response to alpha-gliadin in untreated coeliac disease. Gut 1982; 23: 83-7.

11 Clausen JE. Leukocyte migration agarose technique: some technical details. Acta Allergol (Kbh) 1973; 28: 351-64.

12 Rawcliffe PM, Priddle JD, Jewell DP. Antigenic reactivity of peptides derived from wheat gluten with sera from patients with coeliac disease. Clin Sci 1985; 69: 97-104.

13 Rick W. Trypsin. In: Bergmeyer HU, ed. Methods of enzymatic analysis. New York: Academic Press, 1974: 2nd English edn. Vol 2. 1013-24.
14 Anand BS. University of Oxford: D Phil thesis, 1977.

15 O'Farrelly C, Hekkens WTJM, Feighery C, Weir DG. The specificity of wheat protein reactivity in coeliac disease. Scand J Gastroenterol 1983; 18: 603-7.

16 Simpson FG, Field HP, Howdle PD, Robertson DAF, Losowsky MS. Leucocyte migration inhibition test in coeliac disease - a reappraisal. Gut 1983; 24: 311-7.

17 Ashkenazi A, Levin S, Idar D, Or A, Rosenberg I, Handzel, ZT. Immunological assay for the diagnosis of coeliac disease: interaction between purified gluten fractions. Pediatr Res 1980; 14: 776-8.

18 Corazza GR, Rawcliffe PM, Frisoni M, et al. Specificity of leucocyte migration inhibition test in coeliac disease. A reassessment using different gluten subfractions. Clin Exp Immunol 1985; 60: 117-22. 